\title{
SECONDARY METABOLITES FROM MICROMONOSPORA SP. (G044)
}

\author{
Cao Duc Tuan ${ }^{1,3}$, Truong Bich Ngan ${ }^{1}$, Doan Thi Mai Huong, ${ }^{1,}$, Vu Thi Quyen", \\ Le Thi Hong Minh ${ }^{1}$, Brian Murphy ${ }^{2}$, Chau Van Minh ${ }^{1}$, Pham Van Cuong, ${ }^{1}$, \\ ${ }^{1}$ Institute of Marine Biochemistry-VAST, 18, Hoang Quoc Viet, Cau Giay, Ha Noi, Viet Nam \\ ${ }^{2}$ University of Illinois at Chicago, 700 S Halsted, Chicago, Illinois, USA \\ ${ }^{3}$ Hai Phong University of Medicine and Pharmacy, 72A, Nguyen Binh Khiem, Ngo Quyen, \\ Hai Phong, Viet Nam \\ "Email: doanhuong7@yahoo.com
}

Received: 24 August 2016; Accepted for publication: 28 December 2016

\begin{abstract}
In the course of our screening program, the EtOAc extract of a Micromonospora sp. (strain G044) from sponge Tethya aurantium of the sea of Côtô - Thanh Lân exhibited antimicrobial activity against Enterococcus faecalis, Bacillus cereus and Candida albicans. In this paper, we reported the isolation and structural elucidation of six secondary metabolites Cyclo-(Pro-Trp) (1), Cyclo-(Pro-Met) (2), Cyclo-(Pro-Val) (4), N-acetyltryptamine (3), uridine (5), and 2phenylacetic acid (6) from the cultures broth of Micromonospora sp. (strain G044). The structures of $\mathbf{1}-\mathbf{6}$ were determined by analyses of MS and 2D NMR data. All compounds were evaluated for their antimicrobial activity against a panel of clinically significant microorganisms. Compound 1 inhibited Escherichia coli with a MIC value of $128 \mu \mathrm{g} / \mathrm{ml}$.
\end{abstract}

Keywords: Micromonospora sp., marine microorganisms, antimicrobial activity, Cyclo-(ProTrp), Cyclo-(Pro-Met), Cyclo-(Pro-Val).

\section{INTRODUCTION}

Sponges have been the focus of many studies as they have proved to be a rich source of biologically active secondary metabolites. Since the discovery of spongothymidine and spongouridine in the early 50's [1], a large number of biologically active compounds were isolated from marine sponges and their associated microorganisms [2]. The chemical diversity of sponge-derived products is remarkable and their biological activity ranges from antiinflammatory, antitumour, immuno- or neurosuppressive, antiviral, antimalarial, antibiotic to antifouling [3]. However, many of the bioactive compounds found in sponges are, in fact, produced by their associated microbial communities [4 - 5]. In the course of our screening program, the EtOAc extract of a Micromonospora sp. (strain G044) from sponge of the sea of Côtô -Thanh Lân exhibited an inhibition activity against Enterococcus faecalis, Bacillus cereus and Candida albicans. In this paper, we reported the isolation and structural elucidation of six 
secondary metabolites Cyclo-(Pro-Trp) (1), Cyclo-(Pro-Met) (2), Cyclo-(Pro-Val) (4), Nacetyltryptamine (3), uridine (5), and 2-phenylacetic acid (6) from the cultures broth of Micromonospora sp. (strain G044) (Figure 1). Compound 1 inhibited Escherichia coli with a MIC value of $128 \mu \mathrm{g} / \mathrm{ml}$.<smiles></smiles><smiles>CCCCC1NC(=O)C2CCCN2C1=O</smiles><smiles>CC(C)=CCCc1c[nH]c2ccccc12</smiles><smiles>CC(C)C1NC(=O)[C@@H]2CCCN2C1=O</smiles>

4<smiles>CC(O)Cn1ccc(=O)[nH]c1=O</smiles>

5<smiles>O=C(O)Cc1ccccc1</smiles>

Figure 1. Compounds (1-6) isolated from the culture broth of Micromonospora sp (G044 strain).

\section{MATERIALS AND METHODS}

\subsection{General Experimental procedures}

ESIMS were recorded on an Agilent 1100 LC-MSD Trap spectrometer. NMR spectra were recorded on a Bruker $500.13 \mathrm{MHz}$ spectrometer operating at $125.76 \mathrm{MHz}$ for ${ }^{13} \mathrm{C} \mathrm{NMR}$, and at $500.13 \mathrm{MHz}$ for ${ }^{1} \mathrm{H}$ NMR. ${ }^{1} \mathrm{H}$ chemical shifts were referenced to $\mathrm{CDCl}_{3}$, DMSO- $d_{6}$ and $\mathrm{CD}_{3} \mathrm{OD}$ at $\delta 7.27,2.50$ and $3.31 \mathrm{ppm}$, respectively, while the ${ }^{13} \mathrm{C}$ chemical shifts were referenced to the central peak of at $\delta 77.1\left(\mathrm{CDCl}_{3}\right), 39.5\left(\mathrm{DMSO}-d_{6}\right)$, and $49.0\left(\mathrm{CD}_{3} \mathrm{OD}\right)$. For HMBC experiments the delay $(1 / 2 \mathrm{~J})$ was $70 \mathrm{~ms}$. TLC silica gel Merk $60 \mathrm{~F}_{254}$ was used as Thin-layer chromatography. Column chromatography (CC) was carried out using silica gel 40 - $63 \mu \mathrm{m}$ or Sephadex LH-20.

\subsection{Marine Materials}

The samples of sponge Tethya aurantium (Pallas, 1767) were collected in Côtô - Thanh Lân in April 2014, and were identified by Prof. Do Cong Thung. Voucher specimens were deposited at the Institute of Marine Biochemistry and Institute of Marine Environment and Resources of the Vietnam Academy of Science and Technology, Hanoi, Vietnam.

\subsection{Bacteria isolation, fermentation and identification}

The sponge sample $(1 \mathrm{~g})$ was added to the $10 \mathrm{~mL}$ of sterile sea water in a conical flask. The flask was agitated for about one hour. The sponge was filtered and the filtrate was serially diluted to obtain $10^{-1}$ to $10^{-7}$ dilutions using the sterilized sea water. An aliquot of $100 \mu \mathrm{L}$ of each dilution was spread on the media. Different media like starch, yeast extract, peptone agar (A1), glycerol asparagine agar (GA Agar), humic acid-B vitamin agar (HV Agar) and glucose yeast malt extract agar (GYM) were used for isolation of actinomycetes. The media containing $50 \%$ of sterile sea water were supplemented with rifampicin $(5 \mu \mathrm{g} / \mathrm{mL})$ and nystatin $(25 \mu \mathrm{g} / \mathrm{mL})$ (Himedia Mumbai) to inhibit bacterial and fungal contamination, respectively. The petriplates were incubated upto 3 weeks at $28{ }^{\circ} \mathrm{C}$. The isolated discrete colonies were observed and used for identification. The fermentation of Micromonospora sp (strain G044) was cultured in highnutrient medium (30 g of instant ocean, $10 \mathrm{~g}$ of starch, $4 \mathrm{~g}$ of yeast, $2 \mathrm{~g}$ of peptone, $1 \mathrm{~g}$ of 
calcium carbonate, $40 \mathrm{mg}$ of iron sulfate, and $100 \mathrm{mg}$ of potassium bromate) for 7 days at $28^{\circ} \mathrm{C}$ while shaking at $200 \mathrm{rpm}$. Sequencing $16 \mathrm{~S}$ rRNA method was used for identification of strain G044. The 16S rRNA gene sequencing was carried by DNA Analyzer (ABI PRISM 3100, Applied Bioscience). Gene sequences were handled by BioEdit v.2.7.5. and compared with bacterial 16S rRNA sequences in GeneBank database by NBCI Blast program.

\subsection{Extraction and isolation}

The culture broth (30 L) of Micromonospora sp. (strain G044) was filtered, and then extracted with ethyl acetate ( $15 \mathrm{~L}$ x 5 times). The extract was concentrated in vacuo to give $2.0 \mathrm{~g}$ of ethyl acetate extract. The EtOAc residue was chromatographed on silica gel column, eluted with a solvent gradient of $\mathrm{CH}_{2} \mathrm{Cl}_{2} / \mathrm{MeOH}\left(0\right.$ to $80 \% \mathrm{MeOH}$ in $\mathrm{CH}_{2} \mathrm{Cl}_{2}$ ) to yield 18 fractions. Fraction $7(0.16 \mathrm{~g})$ was chromatographed on a silica gel $\mathrm{CC}$, eluted with mixtures of $\mathrm{CH}_{2} \mathrm{Cl}_{2}$ /acetone ( 0 to $50 \%$ acetone in $\mathrm{CH}_{2} \mathrm{Cl}_{2}$ ), to give five subfractions. Subfraction 7.5 was subjected to $\mathrm{CC}$ on silica gel, eluted with the mixture of $\mathrm{CH}_{2} \mathrm{Cl}_{2} /$ acetone $(95 / 5)$ to obtain 6 (6 $\mathrm{mg})$. Fraction $11(0.13 \mathrm{~g})$ was subjected to Sephadex LH-20 CC $(\mathrm{MeOH})$ to afford five subfractions. Subfraction 11.3 was purified by $\mathrm{CC}$ on silica gel, eluted with mixtures of $\mathrm{CH}_{2} \mathrm{Cl}_{2} /$ acetone $(95 / 5)$ to afford $2(5 \mathrm{mg})$. Subfraction 11.5 was purified by $\mathrm{CC}$ on silica gel, eluted with the mixture of $\mathrm{CH}_{2} \mathrm{Cl}_{2} / \mathrm{EtOAc}(6 / 4)$ to afford $\mathbf{3}(4 \mathrm{mg})$ and $\mathbf{1}(8 \mathrm{mg})$. Fraction 15 was subjected to Sephadex LH-20 CC (MeOH) to afford four subfractions, subfraction 15.2 was purified by $\mathrm{CC}$ on silica gel, eluted with mixtures of $\mathrm{CH}_{2} \mathrm{Cl}_{2} /$ acetone $(9 / 1)$ to afford $4(6 \mathrm{mg})$. Fraction 18 was subjected to Sephadex LH-20 CC (MeOH) to afford seven subfractions. Subfraction 18.6 was purified by TLC preparative using mixtures of $\mathrm{CH}_{2} \mathrm{Cl}_{2}$ /acetone/MeOH (9/1/0.1) to afford 5 (3 mg).

Cyclo-(Pro-Tryp) (1): White solid; ESI-MS: $m / z$ 284.1409 [M-H $]^{+} ;{ }^{1} \mathrm{H}-\mathrm{NMR}(500 \mathrm{MHz}$, $\left.\mathrm{CD}_{3} \mathrm{OD}\right): \delta_{\mathrm{H}}(\mathrm{ppm}) 1.00\left(1 \mathrm{H}, \mathrm{m}, \mathrm{H}_{\mathrm{a}}-5\right), 1.52\left(1 \mathrm{H}, \mathrm{m}, \mathrm{H}_{\mathrm{a}}-4\right), 1.72\left(1 \mathrm{H}, \mathrm{m}, \mathrm{H}_{\mathrm{b}}-4\right), 1.99\left(1 \mathrm{H}, \mathrm{m}, \mathrm{H}_{\mathrm{b}^{-}}\right.$ 5); $3.27\left(1 \mathrm{H}, \mathrm{m}, \mathrm{H}_{\mathrm{a}}-3\right), 3.33(1 \mathrm{H}, \mathrm{m}, \mathrm{H}-10), 3.48\left(2 \mathrm{H}, \mathrm{m}, \mathrm{H}_{\mathrm{b}}-3\right), 4.03(1 \mathrm{H}, \mathrm{m}, \mathrm{H}-6), 4.43(1 \mathrm{H}, \mathrm{m}$, H-9), $7.03\left(1 \mathrm{H}, \mathrm{t}, J=8.0 \mathrm{~Hz}, \mathrm{H}-5^{\prime}\right), 7.11(1 \mathrm{H}, \mathrm{t}, J=8.0 \mathrm{~Hz}, \mathrm{H}-6$ ' $), 7.12\left(1 \mathrm{H}, \mathrm{s}, \mathrm{H}-2^{\prime}\right), 7.35(1 \mathrm{H}$, $\left.\mathrm{d}, J=8.0 \mathrm{~Hz}, \mathrm{H}-7^{\prime}\right), 7.59\left(1 \mathrm{H}, \mathrm{d}, J=8,0 \mathrm{~Hz}, \mathrm{H}-4^{\prime}\right) ;{ }^{13} \mathrm{C}-\mathrm{NMR}\left(150 \mathrm{MHz}, \mathrm{CD}_{3} \mathrm{OD}\right): \delta_{\mathrm{C}}(\mathrm{ppm})$ 22.6 (C-4), 29.1 (C-10), 29.1 (C-5), 45.9 (C-3), 57.2 (C-9), 60.1 (C-6), 109.6 (C-3'), 112.3 (C-7'), 119.8 (C-4'), 120.0 (C-5'), 122.6 (C-6'), 125.6 (C-2'), 128.7 (C-3'a), 138.0 (C-7'a), $167.5(\mathrm{C}=\mathrm{O}) ; 170.8(\mathrm{C}=\mathrm{O})$.

Cyclo-(Pro-Met) (2): White solid; ESI-MS: $m / z 229.10[\mathrm{M}+\mathrm{H}]^{+} ;{ }^{1} \mathrm{H}-\mathrm{NMR}\left(500 \mathrm{MHz}, \mathrm{CDCl}_{3}\right)$ : $\delta_{\mathrm{H}}(\mathrm{ppm}) 1.90\left(1 \mathrm{H}, \mathrm{m}, \mathrm{H}_{\mathrm{a}}-4\right), 2.10\left(2 \mathrm{H}, \mathrm{m}, \mathrm{CH}_{2}-5\right), 2.11\left(1 \mathrm{H}, \mathrm{m}, \mathrm{H}_{\mathrm{b}}-4\right), 2.12\left(3 \mathrm{H}, \mathrm{s}, \mathrm{SCH}_{3}\right), 2.37$ $\left(2 \mathrm{H}, \mathrm{m}, \mathrm{CH}_{2}-10\right), 2.68\left(2 \mathrm{H}, \mathrm{t}, J=6.5 \mathrm{~Hz}, \mathrm{CH}_{2}-11\right), 3.54\left(1 \mathrm{H}, \mathrm{m}, \mathrm{H}_{\mathrm{a}}-3\right), 3.61\left(1 \mathrm{H}, \mathrm{m}, \mathrm{H}_{\mathrm{b}}-3\right), 4.10$ $(1 \mathrm{H}, \mathrm{m}, \mathrm{H}-6), 4.42(1 \mathrm{H}, \mathrm{m}, \mathrm{H}-9) ;{ }^{13} \mathrm{C}-\mathrm{NMR}\left(125 \mathrm{MHz}, \mathrm{CDCl}_{3}\right): \delta_{\mathrm{C}}(\mathrm{ppm}) 15.3\left(\mathrm{SCH}_{3}\right) ; 22.7(\mathrm{C}-$ 4), 28.2 (C-5), 28.9 (C-11), 30.3 (C-10), 45.5 (C-3), 54.6 (C-9), 59.0 (C-6), 165.4 (C=O), 170.3 $(\mathrm{C}=\mathrm{O})$.

2-(3-indolyl) ethylamine acetate (3): White solid; ESI-MS: $\mathrm{m} / z$ $203[\mathrm{M}+\mathrm{H}]^{+} ;{ }^{1} \mathrm{H}-\mathrm{NMR}(500$ $\left.\mathrm{MHz}, \mathrm{CDCl}_{3}\right): \delta_{\mathrm{H}}(\mathrm{ppm}) 1.93\left(3 \mathrm{H}, \mathrm{s}, \mathrm{COCH}_{3}\right), 2.98\left(2 \mathrm{H}, \mathrm{t}, J=6.5 \mathrm{~Hz}, \mathrm{CH}_{2}-1^{\prime}\right), 3.60(2 \mathrm{H}, \mathrm{q}$, $\left.J=6.5 \mathrm{~Hz}, \mathrm{CH}_{2}-2^{\prime}\right), 7.04(1 \mathrm{H}, \mathrm{d}, J=2.0 \mathrm{~Hz}, \mathrm{H}-2), 7.13(1 \mathrm{H}, \mathrm{td}, J=1.0,8.0 \mathrm{~Hz}, \mathrm{H}-5), 7.21(1 \mathrm{H}$, td, $J=1.0,8.0 \mathrm{~Hz}, \mathrm{H}-6), 7.38(1 \mathrm{H}, \mathrm{d}, J=8.0 \mathrm{~Hz}, \mathrm{H}-7), 7.60(1 \mathrm{H}, \mathrm{d}, J=8.0 \mathrm{~Hz}, \mathrm{H}-4), 8.16(1 \mathrm{H}$, br s, NH); ${ }^{13} \mathrm{C}-\mathrm{NMR}\left(125 \mathrm{MHz}, \mathrm{CDCl}_{3}\right): \delta_{\mathrm{C}}(\mathrm{ppm}) 23.4\left(\mathrm{COCH}_{3}\right), 25.3(\mathrm{C}-1$ '), $39.8(\mathrm{C}-2$ '), 111.3 (C7), 113.0 (C-3), 118.7 (C-4), 119.5 (C-5), 122.0 (C-6), 122.3 (C-2), 127.4 (C-3a), 136.4 (C-7a), $170.2(\mathrm{C}=\mathrm{O})$.

Cyclo-(Pro-Val) (4): White solid; ESI-MS: $m / z$ 197.1[M+H] ${ }^{+} ;{ }^{1} \mathrm{H}-\mathrm{NMR}\left(500 \mathrm{MHz}, \mathrm{CD}_{3} \mathrm{OD}\right)$ : $\delta_{\mathrm{H}}(\mathrm{ppm}) 0.95\left(3 \mathrm{H}, \mathrm{d}, J=6.8 \mathrm{~Hz}, \mathrm{CH}_{3}-11\right), 1.11\left(3 \mathrm{H}, \mathrm{d}, J=6.8 \mathrm{~Hz}, \mathrm{CH}_{3}-12\right), 1.94-2.05(3 \mathrm{H}, \mathrm{m}$, 
$\left.\mathrm{CH}_{2}-4, \mathrm{H}_{\mathrm{a}}-5\right), 2.33\left(1 \mathrm{H}, \mathrm{m}, \mathrm{H}_{\mathrm{b}}-5\right), 2.50(1 \mathrm{H}, \mathrm{m}, \mathrm{H}-10), 3.54(2 \mathrm{H}, \mathrm{m}, \mathrm{H}-3), 4.05$ (1H, m, H-6), $4.22(1 \mathrm{H}, \mathrm{m}, \mathrm{H}-9) ;{ }^{13} \mathrm{C}-\mathrm{NMR}\left(125 \mathrm{MHz}, \mathrm{CD}_{3} \mathrm{OD}\right): \delta_{\mathrm{C}}(\mathrm{ppm}) 15.2(\mathrm{C}-11), 17.4(\mathrm{C}-12), 21.8(\mathrm{C}-$ 4), 28.1 (C-5), 28.5 (C-10), 44.8 (C-3), 58.6 (C-9), $60.1(\mathrm{C}-6), 166.2(\mathrm{C}=\mathrm{O}), 171.2(\mathrm{C}=\mathrm{O})$.

Uridine (5): White solid; ESI-MS $(\mathrm{m} / \mathrm{z}): 245.1[\mathrm{M}+\mathrm{H}]^{+} .{ }^{1} \mathrm{H}-\mathrm{NMR}\left(500 \mathrm{MHz}, \mathrm{CD}_{3} \mathrm{OD}\right) \delta(\mathrm{ppm})$ $3.75\left(1 \mathrm{H}, \mathrm{dd}, J=3.0,12.5 \mathrm{~Hz}, \mathrm{H}_{\mathrm{a}}-5 \square\right), 3.86\left(1 \mathrm{H}, \mathrm{dd}, J=2.5,12.5 \mathrm{~Hz}, \mathrm{H}-\mathrm{H}_{\mathrm{b}}-5 \square\right) ; 4.03(1 \mathrm{H}, \mathrm{m}$, $\mathrm{H}-4 \square), 4.17(1 \mathrm{H}, \mathrm{m}, \mathrm{H}-3 \square), 4.20(1 \mathrm{H}, \mathrm{m}, \mathrm{H}-2 \square), 5.72(1 \mathrm{H}, \mathrm{d}, J=8.0 \mathrm{~Hz}, \mathrm{H}-5), 5.92(1 \mathrm{H}, \mathrm{d}$, $J=4.5 \mathrm{~Hz}, \mathrm{H}-1 \square), 8.02(1 \mathrm{H}, \mathrm{d}, J=8.0 \mathrm{~Hz}, \mathrm{H}-6)$.

2-phenylacetic acid (6): White solid. ESI-MS: $\mathrm{m} / z, 136[\mathrm{M}]^{+} .{ }^{1} \mathrm{H}-\mathrm{NMR}\left(500 \mathrm{MHz}, \mathrm{CDCl}_{3}\right)$ : $\delta_{\mathrm{H}}(\mathrm{ppm}) 3.69\left(2 \mathrm{H}, \mathrm{s}, \mathrm{CH}_{2}-7\right) ; 7.30-7.39(5 \mathrm{H}, \mathrm{m}, \mathrm{Ph}-\mathrm{H}) .{ }^{13} \mathrm{C}-\mathrm{NMR}\left(125 \mathrm{MHz}, \mathrm{CDCl}_{3}\right): \delta_{\mathrm{C}}$ (ppm) 41.4 (C-7), 127.2 (C-4), 128.6 (C-2 and C-6), 129.4 (C-3 and C-5), 133.8 (C-1), 175.2 $(\mathrm{COOH})$.

\subsection{Antimicrobial assay}

Antimicrobial assays were carried out using E. coli (ATCC25922), P. aeruginosa (ATCC27853), S. enterica (ATCC12228), E. faecalis (ATCC13124), S. aureus (ATCC25923), B. cereus (ATCC13245), and C. albicans (ATCC1023). Stock solutions of samples were prepared in DMSO, and the antimicrobial assays were carried out in 96-well microtiter plates against the microbial strains $\left(5 \times 10^{5} \mathrm{CFU} / \mathrm{mL}\right)$ using a modification of the published method [6]. After incubation for $24 \mathrm{~h}$ at $37{ }^{\circ} \mathrm{C}$, the absorbance at $650 \mathrm{~nm}$ was measured using a microplate reader. Streptomycin and nystatin were used as reference compounds.

\section{RESULTS AND DISCUSSION}

Compound 1 was isolated as a white solid. In its positive HRESI mass spectrum, the pseudomolecular ion was observed at $\mathrm{m} / \mathrm{z} 284.1409[\mathrm{M}+\mathrm{H}]^{+}$, suggesting a molecular formula of $\mathrm{C}_{16} \mathrm{H}_{19} \mathrm{~N}_{3} \mathrm{O}_{2}$. Analyses of the ${ }^{13} \mathrm{C}$-NMR and DEPT spectra with the aid of the HSQC of $\mathbf{1}$ indicated the presence of 16 carbons, including four $\mathrm{sp}^{3}$ methylenes at $\delta_{\mathrm{C}} 22.6(\mathrm{C}-4), 29.1(\mathrm{C}-$ 10), 29.1 (C-5), 45.9 (C-3), two sp ${ }^{3}$ methines at $\delta_{\mathrm{C}} 57.2$ (C-9), 60.1 (C-6), eight aromatic carbons (five methines and three quaternary carbons) and two carbonyl carbons at $\delta_{\mathrm{C}} 167.4$ and 170.3 . The ${ }^{1} \mathrm{H}$-NMR spectrum of 1 indicated the presence of a 1,2-disubstituted benzene ring $\left[\delta_{\mathrm{H}} 7.03\right.$ $\left(1 \mathrm{H}, \mathrm{t}, J=8.0 \mathrm{~Hz}, \mathrm{H}-5^{\prime}\right), 7.11\left(1 \mathrm{H}, \mathrm{t}, J=8.0 \mathrm{~Hz}, \mathrm{H}-6^{\prime}\right), 7.35$ (1H, d, $\left.J=8.0 \mathrm{~Hz}, \mathrm{H}-7^{\prime}\right), 7.59(1 \mathrm{H}$, d, $\left.\left.J=8,0 \mathrm{~Hz}, \mathrm{H}-4^{\prime}\right)\right]$, a singlet aromatic proton at $\delta_{\mathrm{H}} 7.12\left(1 \mathrm{H}, \mathrm{s}, \mathrm{H}-2^{\prime}\right)$, and ten protons in the aliphatic region. The chemical shifts of CH-6 $\left(\delta_{\mathrm{C}} 60.7, \delta_{\mathrm{H}} 4.03\right), \mathrm{CH}-9\left(\delta_{\mathrm{C}} 57.2, \delta_{\mathrm{H}} 4.42\right)$, and $\mathrm{CH}_{2}-3\left(\delta_{\mathrm{C}} 45.9, \delta_{\mathrm{H}} 3.27,3.48\right)$ suggested their linkage to nitrogen. Analysis of COSY spectrum revealed the presence of three spin - spin coupling systems: $\mathrm{CH}_{2}-3 / \mathrm{CH}_{2}-4 / \mathrm{CH}_{2}-5 / \mathrm{CH}-6 ; \mathrm{CH}-$ 9/CH ${ }_{2}-10$ and $\mathrm{H}-4^{\prime} / \mathrm{H}-5^{\prime} / \mathrm{H}-6^{\prime} / \mathrm{H}^{-} \mathbf{7}^{\prime}$ (Figure 2). These observed data revealed that compound 1 was a cyclodipeptide compound, forming from a proline and tryptophan units. In the HMBC spectrum, the correlation of $\mathrm{H}-10$ with $\mathrm{C}-2, \mathrm{C}-3$ ', C-9, C3a' and C-1 suggested that the indole ring was attached to C-10 (Figure 2). Detailed analysis of 2D NMR spectra, especially HMBC spectrum allowed determining the structure of $\mathbf{1}$ as Cyclo-(Pro-Trp). This cyclodipeptide was previously described $[5,7]$. 


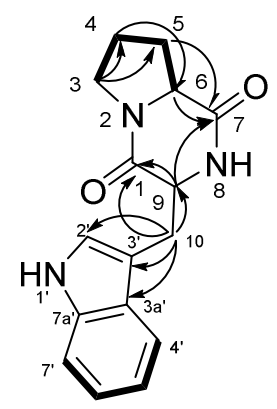

Figure 2. Selected COSY ( $(-)$ and HMBC ( $\bullet$ ) correlations of $\mathbf{1 .}$

Compound 2 was obtained as a white amorphous solid. The ESI-MS indicated the pseudomolecular ion peak at $\mathrm{m} / z 229.10[\mathrm{M}+\mathrm{H}]^{+}$. The ${ }^{1} \mathrm{H}-\mathrm{NMR}$ spectrum of $\mathbf{2}$ displayed signals of a methyl groups at $\delta_{\mathrm{H}} 2.12\left(3 \mathrm{H}, \mathrm{s}, \mathrm{SCH}_{3}\right)$ and signals of 12 aliphatic protons ranging from 1.90 to $4.42 \mathrm{ppm}$. Analysis of the ${ }^{13} \mathrm{C}$ NMR and DEPT spectra of 2 revealed the presence of 10 carbons, including one methyl groups at $\delta_{\mathrm{C}} 15.3\left(\mathrm{SCH}_{3}\right)$, two methines at $\delta_{\mathrm{C}} 54.6(\mathrm{C}-9), 59.0(\mathrm{C}-$ 6), five methylenes at $\delta_{\mathrm{C}} 22.7$ (C-4), 28.2 (C-5), 28.9 (C-11), 30.3 (C-10), 45.5 (C-3), and two carbonyl at $\delta_{\mathrm{C}} 165.4(\mathrm{C}=\mathrm{O})$ and $170.3(\mathrm{C}=\mathrm{O})$. The chemical shifts of $\mathrm{CH}-6\left(\delta_{\mathrm{C}} 59.0, \delta_{\mathrm{H}} 4.10\right)$, CH-9 $\left(\delta_{\mathrm{C}} 54.6, \delta_{\mathrm{H}} 4.42\right)$ and $\mathrm{CH}_{2}-3\left(\delta_{\mathrm{C}} 45.5, \delta_{\mathrm{H}} 3.54\right.$ and 3.61) suggested their linkage to nitrogen atoms. Detailed analysis of the NMR suggested the structure of $\mathbf{2}$ which was a cyclodipeptide compound, forming from a proline and methionine units. Complete analysis of the NMR spectra and comparison with reported NMR data indicated that compound $\mathbf{2}$ was Cyclo-(Pro-Met) [8].

Compound 3 was isolated as a white solid. In its positive ESI mass spectrum, the pseudomolecular ion was observed at $m / z 203[\mathrm{M}+\mathrm{H}]^{+}$. In the ${ }^{1} \mathrm{H}-\mathrm{NMR}$ spectrum, the presence of a 1,2disubstituted benzene ring [ $\delta_{\mathrm{H}} 7.13(1 \mathrm{H}, \mathrm{td}, J=1.0,8.0 \mathrm{~Hz}, \mathrm{H}-5), 7.21(1 \mathrm{H}, \mathrm{td}, J=1.0,8.0 \mathrm{~Hz}$, $\mathrm{H}-6), 7.38(1 \mathrm{H}, \mathrm{d}, J=8.0 \mathrm{~Hz}, \mathrm{H}-7), 7.60(1 \mathrm{H}, \mathrm{d}, J=8.0 \mathrm{~Hz}, \mathrm{H}-4)]$, and a singlet aromatic proton at $\delta_{\mathrm{H}} 7.04(1 \mathrm{H}, \mathrm{d}, J=2.0 \mathrm{~Hz}, \mathrm{H}-2)$ were noted. However, at the aliphatic region of in the ${ }^{1} \mathrm{H}-$ NMR of 3 , the signals of an acetyl at $\delta_{\mathrm{H}} 1.93$, a triplet methylene group at $\delta_{\mathrm{H}} 2.98$ and a quartet methylene group bonded with nitrogen at $\delta_{\mathrm{H}} 3.60$ were observed. The ${ }^{13} \mathrm{C}-\mathrm{NMR}$ and DEPT spectra of $\mathbf{3}$ showed signals of the groups observed above with additional signals of a caboxyl amide group at $\delta_{\mathrm{C}} 170.2$ and three quaternany carbone. Complete analysis of the NMR spectra and comparison with reported NMR data indicated that compound $\mathbf{3}$ was 2-(3-indolyl) ethylamine acetate [9].

Compound $\mathbf{4}$ was isolated as a white solid. The ESI mass spectrum of $\mathbf{1}$ presented a base peak at $\mathrm{m} / z$ 197.1 $[\mathrm{M}+\mathrm{H}]^{+}$. In the ${ }^{13} \mathrm{C}-\mathrm{NMR}$ spectrum, the some signals of protons at the aliphatic region of $\mathbf{4}$ was close of $\mathbf{1}$, including one methylene group attached to nitrogen at $\delta_{\mathrm{C}}$ $44.8(\mathrm{C}-3), 2$ methine $\mathrm{sp}^{3}$ groups bonded with nitrogen at $\delta_{\mathrm{C}} 58.6(\mathrm{C}-9)$ and $\delta_{\mathrm{C}} 60.1(\mathrm{C}-6)$, two carbonyl amide groups at $\delta_{\mathrm{C}} 166.2(\mathrm{C}=\mathrm{O}) ; 171.2(\mathrm{C}=\mathrm{O})$ and two methylen groups at $\delta_{\mathrm{C}} 21.8(\mathrm{C}-$ 4), 28.1 (C-5). The difference between two compounds was the presence of a $-\mathrm{CH}\left(\mathrm{CH}_{3}\right)_{2}$ moiety of 4 instead of a indole ring of compound 1, this observation was based on ${ }^{1} \mathrm{H}-\mathrm{NMR}$ spectra, the signals of two doublet methyl groups at $0.95\left(3 \mathrm{H}, \mathrm{d}, J=6.8 \mathrm{~Hz}, \mathrm{CH}_{3}-11\right), 1.11(3 \mathrm{H}, \mathrm{d}, J=6.8 \mathrm{~Hz}$, $\left.\mathrm{CH}_{3}-12\right)$ and a methine group at $2.50(1 \mathrm{H}, \mathrm{m}, \mathrm{H}-10)$ instead of the indol ring signals of $\mathbf{1}$. These results suggested $\mathbf{4}$ belonging to a diketopiperazine compound. NMR-data comparison with those previously reported defined compound $\mathbf{4}$ to be identical with Cyclo-(Pro-Val) [10-11]. 
Compound $\mathbf{5}$ was obtained as a white solid. The ESI mass spectrum of $\mathbf{5}$ showed a base peak at $\mathrm{m} / \mathrm{z} 245.1[\mathrm{M}+\mathrm{H}]^{+}$. In the ${ }^{1} \mathrm{H}-\mathrm{NMR}$, compound $\mathbf{5}$ displayed signals of two olefin protons at $\delta_{\mathrm{H}} 5.72(1 \mathrm{H}, \mathrm{d}, J=8.0 \mathrm{~Hz}, \mathrm{H}-5), 8.02(1 \mathrm{H}, \mathrm{d}, J=8.0 \mathrm{~Hz}, \mathrm{H}-6)$ and a set of the protons of arabionoside sugar moiety at $\delta_{\mathrm{H}} 3.75\left(1 \mathrm{H}, \mathrm{dd}, J=3.0,12.5 \mathrm{~Hz}, \mathrm{H}_{\mathrm{a}}-5 \square\right), 3.86(1 \mathrm{H}, \mathrm{dd}, J=2.5$, $\left.12.5 \mathrm{~Hz}, \mathrm{H}_{\mathrm{b}}-5 \square\right) ; 4.03$ (1H, m, H-4 $\square$ ); $4.17(1 \mathrm{H}, \mathrm{m}, \mathrm{H}-3 \square)$ ); 4.20 (1H, m, H-2 $\left.\square\right) ; 5.92(1 \mathrm{H}, \mathrm{d}$, $J=4.5 \mathrm{~Hz}, \mathrm{H}-1 \square)$. Comparison of the ${ }^{1} \mathrm{H}-\mathrm{NMR}$ spectrum and TLC of 5 with uridine which was available in our laboratory revealed their similarity. Thus, $\mathbf{5}$ was determined as uridine [12].

Compound $\mathbf{6}$ was isolated as a white solid. The ESI mass spectrum of $\mathbf{6}$ presented a base peak at $\mathrm{m} / \mathrm{z} 138[\mathrm{M}+\mathrm{H}]^{+}$. In the ${ }^{1} \mathrm{H}-\mathrm{NMR}$, compound $\mathbf{6}$ displayed signals of 5 aromatic protons at $\delta_{\mathrm{H}}$ 7.30-7.39 $(5 \mathrm{H}, \mathrm{m}, \mathrm{Ph}-\mathrm{H})$, one singlet methylene at $\delta_{\mathrm{H}} 3.59\left(\mathrm{CH}_{2}-7^{\prime}\right)$. The ${ }^{13} \mathrm{C}-\mathrm{NMR}$ and DEPT spectra of 2 indicated the presence of a phenyl ring at $\delta_{\mathrm{C}}$ 127.2-133.8, one methylene group at $\delta_{\mathrm{C}} 41.4(\mathrm{C}-7)$ and a carbonyl group at $\delta_{\mathrm{C}}$ 175.2. Complete analysis of NMR spectra and comparison with the data reported in the literature allowed determining the structure of $\mathbf{6}$ to be 2-phenylacetic acid [13].

All the isolates were evaluated for their antibacterial activity against Escherichia coli (ATCC25922), Pseudomonas aeruginosa (ATCC27853), Salmonella enterica (ATCC12228), Enterococcus faecalis (ATCC13124), Staphylococcus aureus (ATCC25923), Bacillus cereus (ATCC13245), and antifungal activity against Candida albicans (ATCC1023). Compounds 1 selectively inhibited E. coli with MIC value of $128 \mu \mathrm{g} / \mathrm{mL}$, in comparison with the reference compound, streptomycin (MIC: $32 \mu \mathrm{g} / \mathrm{mL}$ ).

\section{CONCLUSION}

Six secondary metabolites Cyclo-(Pro-Trp) (1), Cyclo-(Pro-Met) (2), Cyclo-(Pro-Val) (4), $\mathrm{N}$-acetyltryptamine (3), uridine (5), and 2-phenylacetic acid (6) were isolated from the cultures broth of Micromonospora sp. (strain G044). Compound 1 inhibited Escherichia coli with a MIC value of $128 \mu \mathrm{g} / \mathrm{ml}$.

Acknowledgements. The authors thank Prof. Do Cong Thung (VAST - Vietnam) for marine sample collection. The Vietnam Academy of Science and Technology (VAST) is gratefully acknowledged for financial support (Grant No: VAST.TĐ.ĐAB.04/13-15).

\section{REFERENCES}

1. Bernan V. S., Greenstein M., Maiese W. M. - Marine microorganisms as a source of new natural products, Adv. Appl. Microbiol. 43 (1997) 57-90.

2. Debbab A., Aly H., Lin W. H., Proksch P. - Bioactive compounds from marine bacteria and fungi, Microb. Biotechnol. 3 (5) (2010) 544-563.

3. Fenical W. - New pharmaceuticals from marine organisms, Trends Biotechnol. 15 (1997) 339-341.

4. Radjasa O. K., Sabdono A. - Screening of secondary metabolites-producing bacteria associated with corals using 16S rDNA-based approach, Journal of Coastal Development 7 (1) (2003) 11-19.

5. Carlson S. K., Marler L., Nam S. J., Santarsiero B., Pezzuto J. M., and Murphy, B.T. Potential chemopreventive activity of a new macrolide antibiotic from a marinederived Micromonospora sp., Mar. Drugs 11 (2013) 1152. 
6. Andrews J. M. - Determination of minimum inhibitory concentrations. Journal of Antimicrobial Chemotherapy 48 (S1) (2001) 5-16.

7. Guowu L., Yue W. , Qingfa Z., Weifang T., Jian W. and Tao L. - A Facile Synthesis of 3Substituted 9H-Pyrido[3,4-b]indol- 1(2H)-one Derivatives from 3-Substituted $\beta$ Carbolines, Molecules 15 (2010) 5680-5691.

8. Kimura R., Nagano T., Kinoshita H. - A new synthetic method for the preparation of $\alpha, \beta-$ didehydroamino acid derivatives by means of a wittig-type reaction. Syntheses of $(2 S$, $4 S)$ - and (2R, 4R)-4-hydroxyprolines, Bull. Chem. Soc. Jpn. 75 (2002) 2517-2525.

9. Ruben F. L., Jacob K., Miguel M., and Tamis D. - A Selective Direct Aldol Reaction in Aqueous Media Catalyzed by Zinc-Proline, Eur. J. Org. Chem. 2005 (24) (2005) 52685276.

10. Wei-Hao H., Peter Y. Z., and Lyle I. - Chiral Recognition Inside a Chiral Cucurbituril, Angew. Chem. 46 (39) (2007) 7425-7427.

11. Sprenger, G. A., Aromatic Amino Acids, Amino Acid Biosynthesis: Pathways, Regulation and Metabolic Engineering, 1st edition, Springer, 2007, 106-113.

12. Rui H., Bochu W., Toshiyuki W., Manyuan W., Liancai Z. and Ikuro A. - Cyclodipeptides from Metagenomic Library of a Japanese Marine Sponge, J. Braz. Chem. Soc. 24 (12) (2013) 1926-1932.

13. Flemming M. P. - A Brief Introduction to NMR Spectroscopy of Proteins, Current Protocols in Protein Science 17 (5) (2000) 1-39.

14. Engels F., Renirie B. F., Hart B. A., Labadie R.P., Nijkamp F.P. - Effects of apocynin, a drug isolated from the roots of Picrorhiza kurroa, on arachidonic acid metabolism, FEBS Lett. 305 (3) (1992) 254-256.

15. Liu K. Q., Xiang C., Zhang M., Li P. and Li B. C.- Chemical constituents of the aerial parts of Cynanchum chinense R. Br, J. Chem. Pharm. Res. 6 (5) (2014) 990-995. 